\title{
STRATEGI KAMPANYE POLITIK PASANGAN JOKOWI-JK PADA PEMILIHAN PRESIDEN 2014
}

\author{
Novita Damayanti, Radja Erland Hamzah \\ Fakultas Ilmu Komunikasi Universitas Prof. Dr. Moestopo (Beragama) \\ novita.damayanti@dsn.moestopo.ac.id, radjaerland@dsn.moestopo.ac.id \\ Diajukan: 21-11-2017; Direview: 21-11-2017; Diterima: 23-12-2017;
}

\begin{abstract}
Jokowi-Jk political campaign in the 2014 Presidential Election won the hearts of the Indonesian people. In this presidential election comes a different figure with a simple style and close to the people. Jokowi - Jk political campaign in 2014 Presidential Election has its own uniqueness and managed to win the presidential election. This study aims to find out how the political campaign strategy of the Jokowi-JK candidate for the president and vice president at the presidential election 2014. Theories and concepts used in this research: political communication, political campaigns, and imaging. The research method used a qualitative approach with constructivism paradigm. Methods of data collection by interview, document analysis and using case study method in this research. Jokowi-JK's political campaign strategy in the 2014 Presidential Election was real enggament with the people. Implementation of campaigns conducted at that time was blusukan, folk party, community participation, and people's campaign. Slogan greetings two so as well as work become part of the campaign. The iconic city-box shirt and white shirt became a symbol for Jokowi-JK supporters.
\end{abstract}

Keyword : political campaign, presidential election, political campaign, politik image

\begin{abstract}
Abstrak
Kampanye politik pasangan Jokowi-Jk pada Pemilihan Presiden 2014 berhasil memenangkan hati rakyat Indonesia dengan terpilihnya pasangan tersebut. Pada Pilpres ini muncul sosok yang berbeda dengan gayanya yang sederhana dan dekat dengan rakyat. Kampanye politik Jokowi - Jk pada Pilpres 2014 memiliki keunikan tersendiri dan berhasil memenangkan pemilihan presiden. Maka penelitian ini bertujuan untuk mengetahui bagaimana strategi kampanye politik pasangan Jokowi-JK capres-cawapres Pilpres 2014. Teori dan konsep yang digunakan pada penelitian ini: komunikasi politik, kampanye politik, debat politik dan pencitraan. Metode penelitian menggunakan pendekatan kualitatif dengan paradigma konstruktivisme. Metode pengumpulan data dengan wawancara, analisis dokumen serta menggunakan metode studi kasus pada penelitian ini. Strategi kampanye politik Jokowi-JK dalam Pilpres 2014 adalah kerja nyata dengan rakyat. Implementasi kampanye yang dilakukan pada saat itu adalah blusukan, pesta rakyat, partisipasi masyarakat, dan kampanye rakyat. Slogan salam dua jadi serta kerja menjadi bagian dalam kampanye tersebut. Ikon kemeja kotak-kota dan kemeja putih menjadi simbol bagi pendukung Jokowi-JK.
\end{abstract}

Kata kunci : kampanye politik, komunikasi politik, pemilihan presiden, citra

\section{PENDAHULUAN}

Tndonesia memasuki sistem politik demokrasi dengan pemilihan presiden secara langsung melalui pemilihan umum. Hal tersebut menjadikan kampanye politik Indonesia mengarah Amerikanisasi yaitu kampanye berubah dari yang bersifat institusional (partai) menjadi lebih personal (kandidat) atau yang disebut sebagai personalisasi politik (personalization of politics) dimana pilihan elektoral pemilih sangat bergantung pada hubungannya dengan kandidat politik (Swanson \& Macini,1996:14-17).Pemilihan Presiden 2014 menjadi salah satu fenomena Amerikanisasi dimana sosok calon presiden menjadi lebih dominan dalam mempengaruhi kemenangan dari pada partai politik pendukung pasangan calon presiden. Jokowi merupakan seseorang yang cukup fenomenal dengan keberhasilan beliau dalam memimpinan 
Solo kemudian memenangkan Pilkada DKI Jakarta. Terpilihnya Jokowi sebagai gubernur DKI Jakarta cukup fenomenal dimana hasil polling selalu memenangkan Fauzi Bowo sebagai pemenang PIlkada dan hasil PIlkada menunjukan Jokowi-Ahok sebagai pemenang Gubernur dan Wakil Gubernur DKI Jakarta. Kemudian sosok Jokowi menjadi euphoria sehingga diumukan sebagai calon presiden dari PDIP yang di damping oleh Jusuf Kalla. Jusuf Kalla merupakan mantan wakil presiden Indonesia 2004-2009, dan pernah mendudukin beberapa jabatan menteri. Keduanya diusung oleh PDIP sebagai calon presiden dan wakil presiden 2014 yang ternyata memenangkan Pilpres 2014.

Sejak mantan Wali Kota Solo, Joko Widodo (Jokowi), sukses terpilih menjadi Gubernur DKI Jakarta, banyak calon pemimpin daerah yang meniru gaya Jokowi dalam menarik simpati pemilih. Kata"blusukan" menjadi sangat tren sejak Jokowi turun ke basis massa ke pasar, menemui petani, atau menemui wong cilik. Jokowi yang apa adanya dan menyatu dengan semua kalangan masyarakat, kemudian menjadi tren calon wali kota, calon bupati, bahkan calon legislatif. Oleh tim suksesnya, mereka diagendakan bertemu dengan calon pemilih. Berdialog dengan pedagang, petani, tukang becak, sopir, dan lainnya. Mencoba berempati, berdialog, dan menyerap problematika dan menyerap aspirasi. Hal ini berarti, figur calon presiden maupun calon pemimpin lainnya yang populer dari hasil survei belum tentu elektabilitasnya juga tinggi pada saat pemilu. Maka, selain melihat popularitas pemilih juga harus mempertimbangkan indikator kualitatif lainnya pada saat memberikan hak suaranya pada pemilu. Pemilih di Indonesia sudah cukup cerdas dan bisa membedakan mana figur calon presiden memiliki rekam jejak baik dan integritas tinggi serta mana yang tidak.

Dalam kajian pustaka ini peneliti memaparkan berbagai hasil survai tentang elektabilitas Joko Widodo sebagai calon Presiden tahun 2014. Pertama, Survai Peneliti Pusat Data Bersatu (PDB) menyatakan bahwa Calon presiden yang paling menonjol di masyarakat saat ini adalah Jokowi, tapi sampai saat ini elektabilitasnya mentok di kisaran 30 persen," kata Peneliti Pusat Data Bersatu (PDB) Didik J Rachbini dalam paparan bertajuk
"Publikasi Hasil Survei Serial PDB: Indonesia Mencari Pemimpin" di Jakarta. Survai yang digelar 7--10 Februari 2014 mencatat elektabilitas Jokowi mencapai 31,8 persen, fluktuatif sejak September 2013 di kisaran 30--40 persen. Sementara itu, Prabowo Subianto menempati urutan kedua dengan elektabilitas yang berbeda jauh yakni 12,8 persen, disusul dengan Dahlan Iskan sebesar 5,8 persen, Wiranto 5,6 persen, Jusuf Kalla 3,3 persen, Megawati Soekarnoputri 2,8 persen, Aburizal Bakrie 2,2 persen, Anies Baswedan 2,2 persen, Mahfud MD 1,7 persen dan Hidayat Nur Wahid 1,3 persen. Kedua, Survai CSIS yang digelar tanggal 7 s.d 17 Maret 2014 menyatakan bahwa hasil wawancara terhadap 1.200 responden yang tinggal di 33 Provinsi hasilnya menunjukkan $45,8 \%$ masih bisa mengubah pilihan partainya dalam Pemilu Legislatif 9 April 2014, begitu pula dalam pemilihan Presiden 49,7 \%masih bisa mengubah pilihannya dari sosok yang saat ini akan mereka pilih.Dukungan terhadap partai jika calon presiden disebutkan secara berturut-turut adalah PDI-P (33,4 \%), Geridra (15,5 \%) dan Golkar (15 $\%)$. Gerindra mengalami kenaikan karena partai tersebut menyebut Prabowo Subianto sebagai calon Presidennya, PDI-P karena menyebut Joko Widodo menyebut sebagai calon Presidennya. Pemilih PDI-P meningkat di Pulau Jawa (dari 23,5 $\%$ menjadi $33,1 \%$ dan di luar Jawa dari 15,6\% menjadi 31,2\% saat disebut nama Joko Widodo

Penelitian itu berbasis perbincangan di media sosial dan lima berita portal di Indonesia selama tahun 2013.Kampanyepolitik tidak hanya menggunakan media massa konvensional melainkan sudah beralih pada teknologi komunikasi yaitu media online lebih tepatnya menggunakan media soasial seperti Facebook dan Twitter. Media social menajdi salah satu alat dalam kampanye politik pada Pilpres 2014 yang sangat cepat dan mudah mengajak masyarakat untuk berpartisipasi secara langsung dalam pemilihan presiden 2014 tersebut. Kampanyepolitikdenganmenggunakan situs jejaring social juga melanda Indonesia.

Berdasarkan latar belakang dan fokus penelitian tersebut,maka peneliti merumuskan masalah penelitian sebagai berikut: "Bagaimana strategi komunikasi politik yang digunakan Joko Widodo-Jusuf Kala pada pemilihan presiden tahun 
2014?'Penelitian ini bertujuan untuk mengetahui Strategi kampanye politik yang digunakan Joko Widodo-Jusuf Kala pada pemilihan presiden tahun 2014; dan Implementasi kampanye politik Joko Widodo-Jusuf Kala pada pemilihan Presiden tahun 2014.

\section{LITERATUR DAN METODOLOGI}

Mc Nair mengutip Denton and Woordward yang memberikan definisi komunikasi politik sebagai berikut: Diskusi tentang alokasi public resources (revenue), official authority (mereka yang diberikan kekuasaan untuk membuat peraturan, keputusan legislative dan eksekutif), dan official sanction (penghargaan atau hukuman oleh Negara). Menurut Mc Nair definisi Denton and Woodward di atas termasuk didalamnya retorika politik verbal dan tulisan, namun tidak termasuk komunikasi simbolik. Sedangkan menurut catatan Mc Nair, Doris Graber berpandanganbahwa komunikasipolitik termasuk didalamnya adalah paralinguistik seperti bahasa tubuh dan tindakan politik seperti boikot dan protes. Mc Nair sependapat dengan padangan Graber, bahkan pakaian apa yang digunakan, gaya rambut, tata rias, logo, dan semua elemen komunikasi yang ditujukan untuk membentuk image politik termasuk dalam komunikasi politik. Dengan bersandar pada definisi dari Denton and Woordward, Mc Nair menekankan komunikasi politik pada adanya intensi/maksud.

Tiga elemen komunikasi politik yang diutarakan oleh Mc Nair (2003: 4), meliputi: organisasi politik, media, dan warga negara. Mc Nair (2003:6) berpendapat, ada tiga elemen dalam komunikasi politik, yaitu: organisasi politik, media, dan warga negara.

Mc Nair kemudian memberikan batasan yang lebih luas tentang komunikasi politik: semua bentuk komunikasi yang dilakukan oleh politisi dan aktor poitik lainnya untuk mencapai tujuan yang spesifik, komunikasi yang ditujukan kepada aktor politik dari individu (non politik) seperti pemilih atau kolumnis di media, dan komunikasi tentang aktor-aktor politik dan aktivitas mereka. Baik yang dimuat dalam pemberitaan media massa maupun dalam bentuk-bentuk media lainnya.

Semua wacana politik termasuk dalam komunikasi politik. Tidak hanya wacana yang bersifat verbal atau pernyataan tertulis, tetapi juga meliputi non verbal seperti gaya berpakaian, gerak-gerik tubuh dan design logo. Menurut Lynda ee Kaid (2004 ), komunikasi politik itu sendiri sebelumnya merupakan pengetahuan antar-disiplin yang mencakup konsep komunikasi, pengetahuan politik, jurnalisme, sosiologi, psikologi, sejarah dan lainnya. Namun hari ini, sebagai sebuah disiplin ilmu, komunikasi politik tidaklah sama dengan berbagai bidang studi tersebut. Komunikasi politik mencerminkan teori komunikasi mencakup riset pendekatan masyarakat dan manusia terhadap komunikasi. Ini berarti sebagai sebuah disiplin ilmu, berdirinya komunikasi politik nampaknya kompromi realitas politik yang terus berkembang sehingga menuntut sebuah teori dan metodelogi tersendiri dalam menghadapi realitas tersebut. Ini pula yang menjadi kecendrungan Fagen dalam Nasution (1990: 24-26) yang mendefinisikan komunikasi politik itu merupakan segala komunikasi yang terjadi dalam suatu sistem politik; dan antara sistem tersebut dengan lingkungnnya. Apalagi komunikasi politik itu sendiri sarat dengan studi mengenai jaringan komunikasi (organisasi, kelompok, media massa, dan saluran-saluran khusus) dan determinasi sosial ekonomi dari polapola komunikasi yang ada pada sistem masyarakat. Komunikasi politik adalah studi tentang strategi penggunaan komunikasi untuk mempengaruhi pengetahuan publik, kepercayaan, dan tindakan politik.

Komunikasi politik menurut Galnoor (dalam Nasution, 1990:28), merupakan infrastruktur politik, yakni suatu kombinasi dari berbagai interaksi sosial dimana informasi yang berkaitan dengan usaha bersama dan hubungan kekuasaan masuk dalam peredarannya. Menurut Alwi Dahlan ( 2005 : 11), komunikasi politik adalah bidang atau disiplin yang menelaah prilaku atau kegiatan komunikasi yang bersifat politik, mempunyai akibat politik, atau pengaruh terhadap prilaku politik. Harsono Suwardi membagi pengertian komunikasi politik dalam dua arti: Pertama, komunikasi politik dalam arti sempit sebagai setiap bentuk penyampaian pesan, baik dalam bentuk lambanglambang, maupun dalam bentuk kata-kata tertulis atau terucap, ataupun dalam bentuk isyarat yang dapat mempengaruhi kedudukan seseorang yang 
berada dalam puncak suatu struktur kekuasaan tertentu.

Mengacu pada Dan Nimmo, yang dikutip Harsono Suwardi, komunikasi politik dalam arti sempit, sebagai suatu komunikasi yang dikategorikan mempunyai nilai atau bobot politik, apabila komunikasi yang dimaksud mempunyai konsekuensi atau akibat politik yang mengatur tingkah laku manusia dibawah kondisi pertentangan (konflik). Kedua, dalam arti luas, komunikasi politik setiap jenis penyampaian pesan, khususnya yang bermuatan informasi politik dari suatu sumber ke sejumlah penerima pesan. Dan Nimmo ( 1990 : 56 ) menguraikan bahwa komunikasi politik memiliki cakupan yang meliputi komunikasi politik, pesan politik, persuasi politik, media komunikasi politik, khalayak komunikasi politik, dan akibat-akibat komunikasi politik. Komunikator merupakan pihak yang memprakarsai penyampaian pesan kepada pihak lain, atau mencerminkan pihak yang memulai dan mengarahkan suatu tindakan komunikasi. Pada komunikasi politik, komunikator dapat memerankan dua posisi, yaitu sebagai narasumber individu dan nara sumber kolektif.

Kampanye merupakan kegiatan komunikasi publik yang dilakukan secara berencana yang bertujuan untuk: memobilisasi dan melibatkan orang-orang untuk terlibat dalam menyebarluaskan informasi tertulis melalui media atau media tidak tertulis (langsung dengan publik) untuk mencegah dan mendorong sikap individu atau publik untuk melakukan dan tidak melakukan suatu tindakan tertentu demi kesejahteraan individu maupun publik pada umumnya; Memberikan tekanan kepada para pemegang kekuasaan atau kewenangan dari para pembuat keputusan (pressurising decision makers) untuk mencari solusi yang bermanfaat bagi kesejahteraanindividu atau publik pada umumnya;

Menginformasikan dan memberikan pendudukan kepada individu atau public dan mempersuasi orang-orang untuk mengerti, memahami, dan melakukan suatu tindakan tertentu. Kampanye mencakup empat elemen yang berbeda namun tidak dapat dipisahkan, yaitu:Kampanye selalu berbasis pada lingkungan (environment) seperti peraturan dan perundang-undangan yang berlaku, struktur media massa dalam suatu negara. Tujuan (objectives) strategi bahwa kampanye diorganisasikan untuk menggalang kemampuan berkomunikasi.Secara langsung atau dengan bantuan media (channels of communication) untuk mendapatkan cara mengkomunikasikan pesan sehingga dapat mencapai sasaran. Dan mempunyai dampak (impact) tertentu bagi audiens yang telah ditargetkan.Kampanye modern didefinisikan sebagai aktivitas dari organisasi partai, pimpinan partai politik tingkat pusat yang dikoordinasikan oleh manajemen yang semakin cermat, bahkan tim sukses nasional membayar jasa konsultan kampanye dari luar, dan biasanya pertama kali para konsultan melakukan jajak pendapat. Kampanye modern ini memanfaatkan secara maksimal semua media massa nasional dan bahkan menjadikan televisi menjadi forum utama kampanye untuk melengkapi kerja dari media lain.

Sementara itu pada tingkat nasional, para politisi dan penasihat profesional melakukan jajak pendapat, mendesain iklan, dan menetapkan tema kampanye, jadwal tur kampanye melalui wisata, konferensi pers untuk emnampilkan berita dan foto, hingga ke pembelian seluruh jam utama dari televisi untuk mempengaruhi pemilih. Selain ciriciri kampanye sebagaimana digambarkan diatas, maka kerja kampanye modern dari cabang-cabang partai pada tingkat lokal diorganisasikan oleh partaipartai pada tingkat nasional dalam suatu kerangka koordinasi kampanye strategis. Kampanye politik merupakan sebuah peristiwa yang bisa didramatisasi. Oleh karena itu, Swanson(1990) dalam Hafied Cangara (2009:287) melukiskan kampanye politik tidak ada bedanya dengan sebuah adegan drama yang dipentaskan oleh para aktoraktor politik. Akan tetapi, Nimmo dan Thomas (1973) dalam Hafied Cangara (2009:287) melihat bahwa sebuah perencanaan kampanye politik sedapat mungkin harus melalui tiga fase, yakni: (1) fase pengorganisasian (organizing phase); (2) fase pengujian (testing phase); (3) fase kritis (critical phase).

HafiedCangara(2009:288-289)mengemukakan rumusan yang dibuat oleh Nimmo, pakar lain juga mengemukakan ada enam langkah yang bisa ditempuh dalam perencanaan komunikasi untuk kampanye, yakni: pertama, analisis khalayak (audience) dan kebutuhannya; kedua penetapan sasaran atau tujuan komunikasi; ketiga, rancangan strategi yang mencakup; komunikator, 
saluran (media), pesan dan penerima; keempat, penetapan tujuan pengelolaan(management objectives); kelima, implementasi perencanaan yang mencakup; besarnya dana, sumber dana dan waktu; dan keenam, evaluasi yang mencakup; evaluasi formatif dan evaluasi summatif.

Dalam komunikasi politik, kampanye merupakan bagian yang sangat penting untuk mempengaruhi pemilih. Berikut diuraikan perbedaan antara Kampanye Pemilu dengan Kampanye Politik. Menurut Lock dan Harris dalam Firmanzah (2008:272) kampanye politik terkait erat dengan pembentukan image politik. Dalam kampanye politik terdapat dua hubungan yang akan dibangun, yaitu internal dan eksternal. Hubungan internal adalah suatu proses antara anggota-anggota partai dengan pendukung untuk memperkuat ikatan ideologis dan identitas mereka. Sementara hubungan eksternal dilakukan untuk mengkomunikasikan image yang akan dibangun kepada pihak luar partai, termasuk media massa dan masyarakat secara luas. Kampanye politik menurut Firmanzah memiliki tujuan untuk pembentukan image politik oleh karena itu maka public relations akan sangat dibutuhkan.

Situasi politik Indonesia mempengaruhi bagaimana orientasi kegiatan Public relations (PR) di Indonesia. PR yang sebelumnya sangat terbatasi perannya dalam suatu organisasi maka kini terjadi perubahan peran PR. Masa reformasi yang dituntut untuk terbuka dan trasparan maka peran PR harus berlaku terbuka dengan komunikasi dua arah yang yang tidak hanya mengutamakan kepentingan organisasi saja. Habitat PR sebenarnya pada sistem politik yang demokrasi. Iklim politik Indonesia yang menuju demokratis memungkinkan perkembangan profesi PR yang dalam pendekatanya bersifat holistik. Artinya PR dapat dilihat sebagai tindakan komunikasi untuk membangun citra dan reputasi organisasi dan dijalankan dengan memperhatikan kaidah-kaidah manajemen.

Menurut James E. Grunig, (1992) dalam Rosadi Ruslan (2007 : 61) perkembangan public relations dalam praktik terdapat 4 model, baik secara konseptual maupun secara praktisi dalam manajemen komunikasi. Model-model tersebut adalah.Model agensi pers atau model propaganda. Secara praktik PR/Humas pada tahap ini melakukan propaganda melalui komunikasi searah untuk tujuan memberikan publisitas yang menguntungkan, khususnya ketika berhadapan dengan media massa. Walaupun terkadang pemberian informasinya tidak jujur atau mengandung ketidakbenaran sebagai upaya memanipulasi hal negatif atas lembaga atau organisasinya.; Model informasi public. Dalam hal ini PR/Humas bertindak sebagai wartawan dalam menyebarluaskan informasi kepada publik dan mengendalikan berita atau informasinya kepada media massa. Bentuk ini lebih baik dan mengandung lebih banyak kebenaran karena penyebarannya dilakukan melalui news letter, brosur dan surat langsung (direct mail).

Kedua model tersebut di atas-Press Agency dan Public Information-termasuk model asimetris. Kedua model tersebut pernah dimanfaatkan oleh Ivy L. Lee, praktisi konsultan dan perintis Humas Amerika Serikat, untuk mengatasi pemogokan buruh di Industri batu bara pada tahun 1906. Penyampaian pesannya tidak berdasarkan riset dan perencanaan.; Model asimetris dua arah (two way asymmetrical model). Pada tahap ini, pihak PR dalam praktiknya melalui penyampaian pesannya berdasarkan hasil riset dan strategi ilmiah (scientific strategy) untuk berupaya membujuk publik, agar mau kerja sama, bersikap dan berpikir sesuai dengan harapan organisasi.; Model simetris dua arah (two way symmetrical model). Model ini, PR/Humas melakukan kegiatan berdasarkan penelitian dan menggunakan teknik komunikasi untuk mengelola konflik dan memperbaiki pemahaman public secara strategik (Grunig, 1992: 18).Model paling terakhir ini lebih dapat diterima dan dianggap lebih etis dalam hal penyampaian pesan, informasi, komunikasi yang dapat membujuk untuk membangun saling pengertian, pemahaman dan mempercayai antara kedua belah pihak (Jefkins,1999). Segala kegiatan PR terkait dengan usaha membangun, memelihara, meningkatkan, dan memulihkan citra dan reputasi.

Peran PR politik dalam mendesain citra kandidat menurut Hafied Cangara (2009: 286), tidaklah berdiri sendiri antara partai politik dengan media, tetapi jauh lebih dalam lagi. Dengan kata lain, peran PR politik sudah masuk dalam kehidupan pribadi kandidat untuk menjembatani komunikasi kandidat dengan pemilih lebih dalam. Dialah yang memberi isi pidato, membuat agenda dan pernyataan (statement) politik yang diucapkan 
kandidat, hingga sampai pada gerak-gerik, mimik, retorika, dan kebiasaan yang di permak harus betul-betul "mengesankan" dan "mengagumkan"; berharap munculnya simpati dari pemilih.

Hal di atas merupakan bagian dari PR, seperti yang diuraikan oleh Mc. Nair (2003 : 131-134) terdapat 4 kegiatan penting yaitu: pertama, image Management adalah tugas PR dalam membentuk image personal politisi yang semestinya menyatu dan pas dengan tujuan-tujuan organisasi politik yang dipasarkan. Kedua, information Management, Mc. Nair menilai Information Management yang dilakukan oleh PR politik harus dapat membedakannya dengan jenis media management. Dengan menyeleksi informasi, PR akan dapat membedakan mana informasi konstruktif, dan mana juga propaganda. Informasi yang diterima dari pihak rival kandidat, jelas menggerakkan menggali kebenaran informasi yang diterima. Ketiga, media management, juga merupakan kegiatan PR yang paling utama yang terkait langsung dengan media massa dan menyampaian pesan politik. Dan keempat, internal communication, menekankan pentingnya kordinasi dalam partai politik ataupun organisasi politik. Akan tetapi, dalam memasarkan identitas dan image politik, menurut Mc. Nair, bukan pula sekedar menempatkan pesan di media dengan membayar saja, atau mendesain logo partai, mengatur tata bahasa yang dipakai pada saat wawancara, namun lebih itu juga menilai keseluruhan kerja partai pada saat melakukan kampanye publik.

Citra adalah transaksi antara strategi seorang kandidat dalam menciptakan kesan personal dengan kepercayaan yang sudah ada dalam benak para pemilih. McGinnis, 1970 dalam Kavanagh 1995: 13, pemilih sesungguhnya melihat kandidat bukan berdasarkan realitas yang asli melainkan dari sebuah proses kimiawi antara pemilih dan cintra kandidat (gambaran imajiner). Pembentukan citra politik terkait dengan sosialisasi politik ditegaskan oleh Arifin (2003:107). Citra politik mencakup 3 hal:Seluruh pengetahuan politik seseorang, baik benar maupun keliru.; Semua referensi yang melekat pada tahap tertentu dari peristiwa politik yang menarik.; Semua pengharapan yang dimiliki orang tentang apa yang mungkin terjadi jika ia berprilaku dengan cara berganti-ganti terhadap obyek dalam situasi itu.
Membangun sebuah image politik bukan hal yang mudah, karena tidak semua faktor dapat dipengaruhi atau dikontrol oleh partai politik. Faktor seperti pesaing, politik dapat 'mengganggu' usaha suatu partai politik dalam menciptakan image positif. Dalam iklim persaingan, masingmasing partai politik berusaha menanamkan kesan positif kepada masyarakat. Kenyataan ini membuat banyak sekali image yang harus direkam dalam benak masing-masing individu, sehingga menyulitkan individu untuk mengingat image apa yang ingin diciptakan oleh suatu partai politik. Selain itu, faktor latar belakang individu seperti agama, suku, ras, pendidikan, jenis kelamin, lokasi, dan umur juga memengaruhi suatu masyarakat dalam berpikir dan bertindak. (Firmanzah, 2008 : 241)

Selain itu, gangguan (noise) juga sering muncul, seperti ketidaktepatan menggunakan media komunikasi tertentu, frekuensi yang kurang atau berlebihan atas transfer pesan, dan bias persepsi dalam media massa juga dapat menjauhkan pemahaman yang diinginkan partai politik dengan apa yang dipersepsikan masyarakat. (Firmanzah, 2008 : 241). Membangun image politik dan sampai di masyarakat sesuai dengan apa yang diharapkan suatu partai politik bukanlah hal yang mudah dan dapat cepat dicapai. Untuk itu, ada hal yang harus dilakukan terus-menerus oleh partai politik, yaitu komunikasi politik (political communication). Komunikasi politik tidak hanya terjadi sewaktu periode kampanye politik, melainkan melekat juga pada pemberitaan dan publikasi atas apa saja yang telah, sedang dan akan dilakukan oleh partai politik bersangkutan. Komunikasi politik adalah proses tukar-menukar informasi antara dua entitas atau lebih. Tujuan utama dari komunikasi politik adalah menciptakan kesamaan pemahaman politik (misalnya, pesan, permasalahan, isu, kebijakan politik) antara suatu partai politik dengan masyarakat. Komunikasi dalam hal ini lebih dilihat sebagai komunikasi dua arah dan bukan top-down (hanya dari partai politik ke masyarakat). (Firmanzah, 2007:242). Hasil dari proses pembelajaran dan identifikasi inilah yang akan tertanam dalam benak masing-masing individu yang nantinya menjadi citra, reputasi dan kesan tentang suatu partai politik. (Firmanzah, 2007 : 245). 
Paradigma konstruktivis memandang ilmu sosial sebagai analisis sistematis terhadap socially meaningful action melalui pengamatan langsung dan terperinci terhadap pelaku sosial dalam setting kehidupan sehari-hari yang wajar atau alamiah agar mampu memahami dan menafsirkan bagaimana para pelaku sosial menciptakan dan memelihara dunia sosial mereka (Salim, 2006 : 71). Pelaku sosial yang dimaksud adalah Jokowi yang apabila maju sebagai calon presiden Tahun 2014 merupakan figure yang diidolakan masyarakat.Mengingat paradigma yang digunakan adalah paradigma konstruktifis, maka metode penelitian yang digunakan adalah metode kualitatif. Menurut Moleong (2006: 9) metode penelitian yang sesuai dengan paradigma konstruktifis adalah metode kualiitatif, yaitu sebuah penelitian yang bermaksud memahami fenomena yang dialami oleh subyek penelitian mengenai perilaku, motivasi, tindakan dan lain-lain secara holistic pad suatu konteksa khusus yang alamiah dengan memanfaatkan berbagai metode ilmiah. Penelitian kualitatif membawa peneliti untuk memasuki daan melibatkan sebagian waktunya pada kegiatan atau aktivita obyeknya. Penelitian kualitatif menurutBogdandan Taylor(dalam Moleong,2006:4) merupakan prosedur penelitian yang menghasilkan data deskriptif berupa kata-kata tertulis atau lisan dari orang-orang dan perilaku yuang diamati. Hasil yang diinginkan berupa pemaparan mendalam mengenai permasalahan yang diteliti dengan mengumpulkan data lapangan dan indepth interview dengan anara sumber.yang menggambarkan atau menjelaskan suatu masalah. Menurut Kriyantono ( 2009 ; 59) penelitian kualitatif memiliki ciri-ciri sebagai berikut:"peneliti merupakan instrument pokok penelitian; menggunakan analisis data lapangan, melakukan perekaman data lapangan yang sangat hati-hati, melaporkan detail kondisi lapangan termasuk kutipan-kutipan dan bukti-bukti documenter, memandang ralitas sebagai konstruksi sosial yang dinamis, realitas adalah holistic yang tidak dapat dipilah-pilah, lebih pada kedalaman isi dari pada keluasan, prosedur penelitian empiricrasional dan tidak tgerstruktur, serta hubungan antara teori, konsep dan data dapat memunculkan teori baru".

Dalam penelitianini peneliti melakukan penelitian lapangan atau field research atau natural observation, dan focused intervewies dengan mengumpulkan data-data lapangan dan keterangan yang dibutuhkan baik secara langsung maupun tidak langsung. Penelitian dapat didefinisikan menurut para ahli di antaranya yang dikemukakan Sugiyono (2005: 01) bahwa Penelitian lapangan merupakan cara ilmiah untuk mendapatkan data dengan tujuan dan kegunaan tertentu. Menurut Mulyana (2001:201), Studi Kasus adalah metode riset yang menggunakan sebanayak mungkin data yang bisa digunakan untuk meneliti, mengurai, dan menjelaskan secara komprehensif berbagai aspek individu, kelompok, suatu program, organisasi atau peristiwa secara sistematis. Obyek penelitian adalah gejala atau fenomena dan lembaga yang menjadi kajian penelitian, sedang Subyekpenelitian adalah individu yang menjadi sumber informasi yang ditetapkan oleh peneliti untuk diperoleh informasi tentang hal tersebut (Sugiyono 2005;11).Dalam penelitian ini yang menjadi obyek peneltian adalah fenomenafenomena empiric tentang kegiatan Joko Widodo beserta kelompoknya dalam melalukan kampanye politik dalam rangka memenangkan dirinya pada Pemilihan Presiden Republik Indonesia pada bulan Juli 2014.

Sedang yang dimaksud Subyek Penelitian adalah orang-orang yang ditunjuk dan dapat dijadikaan sebagai informan, karena memiliki informasiinformasi atas peristiwa atau perilaku dari individuindividu yang diamati, ditelusur dan dikaji secara individual atau sosial (Miles, 1992:47). Parameter untuk pemilihan subyek penelitian tersebut adalah individu yang memahami tentang: latar, pelaku, peristiwa dan proses dari obyek penelitian. (Miles, 1992 : 56). Bertolak dari pendapat Miles tersebut maka yang menjadi subyek atau narasumber penelitian adalah para pengusung/konsultan komunikasi Jokowi dalam kampanye Pilpres 2014, tokoh masyarakat dan pengamat komunikasi politik. Teknik pengumpulan data yang dipakai dalam penelitian ini meliputi wawancara, observasi dan studi dokumen.

\section{TEMUAN DAN DISKUSI}

Berdasarkan dari data-data yang peneliti himpun dengan wawancara dan studi dokumen maka diperoleh berbagai temuan sebagai bahan analisis pada penelitian strategi komunikasi politik Jokowi- 
JK pada Pilpres 2014. Terdapat dua koalisi besar yaitu Koalisi Indonesia Hebat dan Koalisi Merah Putih dalam Pemilu Presiden tahun 2014. Koalisi Indonesia Hebat yang mengusung pasangan Jokowi-JK memenangkan pemilu presiden 2014. Strategi komunikasi politik Jokowi-JK pada pilpres 2014 dari tim pemenangan adalah dengan merubah pola kampanye konvensional dengan pola kampanye langsung mempertemukan kandidat dengan pemilih. Penggunaan strategi komunikasi politik dengan kampanye secara langsung sesuai dengan jargon kampanye dari pasangan Jokowi-JK yaitu "Jokowi adalah Kita" yang menggambarkan Jokowi adalah bagian dari rakyat sebagai pemilih dan hal ini mencerminkan antara Jokowi dengan rakyat terjalin hubungan emosional yang baik.

Swanson dan Nimmo (1990), menitik beratkan komunikasi politik adalah studi tentang strategi penggunaan komunikasi untuk mempengaruhi pengetahuan publik, kepercayaan, dan tindakan politik; serta studi terhadap keterkatitan kampanye politik sebagai suatu obyek. Menurut tim pemenangan Jokowi-Jk strategi komunikasi politik yang mereka gunakan adalah strategi kampanye dengan komunikasi secara langsung, media, dan gotong royong. Bentuk kampanye yang mempertemukan langsung dengan pemilih. Baik door to door yang dilakukan oleh tim pemenangan dengan mengarahkan semua kader dari SabangMerauke. Berbagai bentuk komunikasi dalam kampanye Pilpres 2014 yang dilakukan oleh tim pemenagan Jokowi-JK adalah : tatap muka, road show, debat Pipres di media massa, media online, sampai dengan blusukan pada lokasi-lokasi rakyat.

Kampanye politik adalah periode yang diberikan panitia pemilu kepada semua kontestan, baik partai politik atau perorangan, untuk memaparkan program-program kerja dan memengaruhi opini publik sekaligus memobilisasi masyarakat agar memberikan suara kepada mereka sewaktu pencoblosan (Lilleker \& Negrine, 2000). Pada masa kampanye pemilihan presiden Indonesia secara langsung tahun 2014 terdapat periode waktu kampanye yang ditentukan oleh KPU sehingga kampanye politik ini adalah kampanye pemilu yang pada saat itu mengarahkan agar kalayak untuk memilih kandidat capres Jokowi-JK pada Pilpres 2014. Sementara itu pada tingkat nasional, para politisi dan penasihat profesional melakukan jajak pendapat, mendesain iklan, dan menetapkan tema kampanye, jadwal tur kampanye melalui road show, konferensi pers untuk menampilkan berita dan foto, hingga ke pembelian seluruh jam utama dari televisi untuk mempengaruhi pemilih. Selain ciri-ciri kampanye sebagaimana digambarkan diatas, maka kerja kampanye modern dari cabangcabang partai pada tingkat lokal diorganisasikan oleh partai-partai pada tingkat nasional dalam suatu kerangka koordinasi kampanye strategis. Hal ini juga terjadi pada calon presiden Jokowi atau Joko Widodo yang telah menjadi sorot media massa semenjak beliau mencabat Wali kota Solo kemudian menjadi Gubernur DKI Jakarta. Salah satu ciri Jokowi dengan blusukannya menjadi identitas dan personal politik dari Jokowi. Jusuf Kalla yang dikenal dengan JK memiliki personal politik dengan gaya bicaranya yang to the point atau terus terang dan pengambilan keputusan yang cepat. Hafied Cangara (2009: 288-289) mengemukakan rumusan yang dibuat oleh Nimmo, pakar lain juga mengemukakan ada enam langkah yang bisa ditempuh dalam perencanaan komunikasi untuk kampanye, dan beberapa dilakukan dalam kampanye JokowiJK. Pada tahap ini tim pemenangan Jokowi$\mathrm{Jk}$ melakukan berbagai riset untuk mengetahui pemetaan dan kebutuhan masing-masing warga pada setiap daerahnya. Analisis khalayak tidak hanya melihat dari faktor demografis dan geografis melainkan juga secara konprehensif melakukan pemetaan pemilih. Elektabilitas Jokowi terpandau secara tersistem untuk menentukan bagian dari pembentukan strategi. Khalayak sasaran adalah seluruh warga negara Indonesia yang memiliki hak pilih baik yang berada di wilayah RI ataupun di luar negeri. Pola konsumsi media masyarakat juga menjadi bagian dari analisis yang dilakukan oleh tim pemenangan Jokowi-JK dalam perencanan media (media planner). Saat ini media online juga menjadi salah satu penyumbang komunikasi terbesar dalam kampanye pilres 2014. Pengguna media online Indonesia yang menduduki urutan 4 dunia menjadi alasan penggunaan media online sabagai salah satu tool/ alat dalam kampanye Pilpres 2014 dari tim pemenangan Jokowi-Jk.

Tujuan dari kampanye ini adalah memenangkan pemilihan Pilpres 2014. Sedangakan tujuan komunikasi kampanye Pilpres Jokowi -Jk terdapat 
beberapa; (1) Membuat masyarakat Indonesia mengetahui Jokowi dan JK sebagai capres 2014. (2) Menyampaikan program kerja calon pemerintahan capres Jokowi-Jk. (3) Mendengarkan dan menampung berbagai aspirasi masyarakat Indonesia dan (4) Menjadikan masyarakat Indonesia sebagai bagian dari kampanye dan bagian dari Jokowi-JK. Sasaran yang dituju adalah seluruh warga negara Indonesia yang telah memiliki hak pilih dalam Pemilu 2014. Khalayak sasaran yang beragam membuat tim pemenangan harus jeli dalam memanfaatkan media yang tepat untuk mencapai khalayak sasaran yang tepat. Pemilih awal yang baru pertama kali memilih yaitu pelajar dan mahasiswa. Masyarakat baik di perkotaan dan daerah di seluruh penjuru Indonesia. Serta warga negara Indonesia yang berdomisili di luar negeri juga menjadi khalayak sasaran dalam kampanye tersebut.

Strategi yang dilancarkan adalah komunikasi langsung, media, dan gotong royong. Partisipasi simpatisan secara langsung membuat kampanye ini menjadi istimewa. Berbagai bentuk komunikasi dalam kampanye Pilpres 2014 yang dilakukan oleh tim pemenagan Jokowi-JK adalah : tatap muka, road show, debat Pipres di media massa, media online, sampai dengan blusukan pada lokasi-lokasi rakyat. Komunikator utama dalam kampanye ini adalah capres Jokowi. Jokowi sebagai komunikator dinilai memiliki similarity dan humble yaitu rakyat Indonesia bila melihat dan mendengar cara bicara Jokowi yang sama dengan masyarakat pada umumnya dengan Bahasa yang lebih informal dan merakyat. Kerendahan hati Jokowi sebagai komunitor tercermin dengan prilakunya yang tidak membatasi diri terhadap masyarakat. Komunikasi nonverbal Jokowi yang tidak menunjukan bahwa beliau memiliki kedudukan yang sama dengan masyarakat dari cara memandang, sentuhan, intonasi, dan gesture beliau.

Komunikator lainnya dalam kampanye ini adalah tim pemenangan dan juga beberapa tokohtokoh yang aktif pada kampanye pilpres 2014 .

Komunikator simpatisan pendukung Jokowi-JK dari kalangan arti dan pemuda yang banyak terlibat secara sukarela untuk meranmaikan sebagai juru kampanye ataupun membuat iklan maupun lagu. Strategi yang saat ini banyak digunakan adalah bauran media. Yaitu memanfaatkan berbagai jenis media baik media konvensional maupun media online. Media online menjadi salah satu media untuk mengena pada khalayak pemilih muda.

Pesan yang disampaikan adalah program kerja yang akan dilaksanakan selama masa pemerintahan bila memenangkan Pilpres 2014. Selain itu pesan yang mengena adalah slogan : "Salam dua Jari"

Slogan ini dibuat sesuai dengan nomor urut dalam pencalonan pilpres 2014. Sehingga bentuk pesan salam dua jari dapat diartikan sebagai symbol perdamaian ( peace pada umumnya) ataupun 2 sebagai nomor urut Jokowi-Jk pada Pilpres 2014. Salah satu ciri pada saat kampanye pilpres 2014 adalah kemeja kotak-kotak merah putih hitam yang menjadi penanda bagi pendukung JokowiJk. Atribut tersebut selai menjadi ciri bagi Jokowi maupun tim pemenangan menjadi stribut yang masyarakat gunakan untuk menunjukan dukungan pada pasangan Jokowi-Jk.

Beberapa kegiatan pada kampanye Pilprs 2014 yang merupakan implementasi dari strategi kampanye pasangan Jokowi - Jk, diantaranya adalah : blusukan, pesta rakyat, dan debat Pilpres 2014. Jokowi memiliki keunikan dalam perannya sebagai capres 2014 yaitu blusukan. Blusukan merupakan suatu aktifitas yang beliau lakukan semenjak menjabat sebagi Walikota Solo. Kebiasaan ini masih tetap ada sampai dengan belia menjadi Gubernur DKI Jakarta. Blusukan merupakan bentuk komunikasi politik yang dilakukan oleh Jokowi-Jk pada kampanye Pilpres 2014. Jokowi dan JK mendatangi berbagai tempat yang terkait dengan kepentingan masyarakat umum di Indonesia. Pasar menjadi salah satu lokasi blusukan capres Jokowi-Jk pada saat kampanye. Blusukan bukan hanya dating tapi juga melakukan komunkasi dua arah denga masyarakat sekitar secara langsung. Dengan gaya bicara Jokowi yang sangat biasa sehingga membuat masyarakat mudah untuk menyampaikan masukan pada Jokowi. Dengan tampilan yang sederhana dalam berpakaian membuat Jokowi diteriam masyarakat saat blusukan sehingga tidak ada batasan yang sangat jauh dalam penampilan.

Salah satu ciri pada saat kampanye pilpres 2014 adalah kemeja kotak-kotak merah putih hitam yang menjadi penanda bagi pendukung JokowiJk. Atribut tersebut selai menjadi ciri bagi Jokowi maupun tim pemenangan menjadi atribut yang 
masyarakat gunakan untuk menunjukan dukungan pada pasangan Jokowi-Jk.Pesta rakyat merupakan salah satu kegiatan besar yang diselenggarakan oleh teman Jokowi pada kampanye Pilpres 2014. Dengan salam 2 jari membuat masyarakat hadir untuk berpartisipasi. Kegiatan konser yang dipenuhi oleh artis nasional yang datang secara suka rela sebagai teman Jokowi membuat suasana makin meriah.

Debat sebagai salah satu bentuk dari komunikasi politik yang melibatkan 3 elemen komunikasi politik yaitu: tim sukses Jokowi-JK, media massa, dan warga negara Indonesia. Mc Nair (2010:6) berpendapat, ada tiga elemen dalam komunikasi politik, yaitu: organisasi politik, media, dan warga negara. Debat pilpres 2014 lalu merupakan ajang bagi Jokowi-JK menampilkan program-program kerja dalam kampanye Pilpres 2014 melalui media massa khususnya televisi. Sebagai komunikator politik Jokowi-JK melakukan (Impression management) pengelolaan kesan untuk menunjukan gambar diri yang akan diterima oleh khalayak. Goffman dalam Mulyana (2010:112) mengasumsikan bahwa ketika orangorang berinteraksi, mereka ingin menyajikan suatu gambaran-diri yang akan diterima orang lain dan upaya ini disebut sebagai "pengelolaan kesan" (impression management), yakni tehnik-tehnik yang digunakan aktor untuk memupuk kesankesan tertentu.

Tim pemenangan Jokowi-JK sebagai organisasi politik menyiapkan kandidatnya untuk debat Pilpres 2014. Jokowi-JK menjadi komunikator dalam debat untuk menyampaikan programprogram politiknya dengan tujuan memenangkan Pilpres 2014. Masyarakat bisa turut berpartisipasi dengan mengikuti polling sms untuk memilih kandidat capres-cawapres Pilpres 2014. Mc Nair (2003:4) memberikan batasan yang lebih luas tentang komunikasi politik: Semua bentuk komunikasi yang dilakukan oleh politisi dan aktor poitik lainnya untuk mencapai tujuan yang spesifik, komunikasi yang ditujukan kepada aktor politik dari individu (non politik) seperti pemilih atau kolumnis di media dan komunikasi tentang aktor-aktor politik dan aktivitas mereka. Baik yang dimuat dalam pemberitaan media massa maupun dalam bentuk-bentuk media lainnya.

Debat merupakan bentuk komunikasi politik yang bertujuan untuk membentuk pencitraan dan memperoleh suara dalam Pilpres 2014. Posisi masing-masing tergambar pada bagan di bawah ini yang menunjukan media berada di tengah atau sentral dan tim pemenangan serta warga negara berada di luar. Tayangan debat merupakan komunikasi politik yang berada pada publik area yang seharusnya semua memiliki posisi dan kedudukan yang sama pada tiap kandidat caprescawapres 2014.

Menurut J.J. Auer(Perloff, 1998:380) pada debat harus terdapat: (1). Konfrontasi, (2). Seimbang dan waktu yang cukup luas ,(3). Kandidat yang setara, (4). Proposisi pernyataan, (5). Untuk membuat keputusan khalayak. Debat Capres-cawapres pada Pilpres 2009 memenuhi beberapa kriteria debat yaitu:kandidat yang seimbang, proposisi pernyataan, dan untuk membuat keputusan khalayak. Terdapat kekurangan yaitu dari sisi waktu menjawab dimana waktunya sangat terbatas untuk menjawab pertanyaan hanya 2 menit. Konfrontasi dalam debat Pilpres 2014 tidak terjadi secara langsung sehingga debat tersebut seakan hambar dengan jawaban yang sangat terbatas dan seakan akan hanya menjadi ajang reuni bagi kandidat capres-cawapres pada saat pilpres 2014. Penonton yang hadir di lokasi debat tidak diperbolehkan untuk memberikan komentar, tepuk tangan dan keributan lainnya. Myles Martel dalam Perloff (1998:380) mendefinisikan debat kampanye politik sebagai, "penampilan bersama dua atau lebih kandidat yang berlawanan, yang menempati posisinya masingmasing, dengan pernyataan yang langsung untuk memperoleh dukungan tanpa adanya interupsi". Definisi ini lebih mendekati pada debat politik karena adanya pertemuan dalam satu tempat, face to face, dan diskusi.

Terdapat beberapa jenis debat menurut Perloff (1998:380-383): Press conference format.The town meeting debate, dan A single moderator format. Debat capres-cawapres pada Pilpres 2014 termasuk jenis debat a single moderator format merupakan satu moderator yang akan memberikan pertanyaan. Lebih teratur dan isu yang akan ditanya lebih fokus namun waktu yang diberikan pada kandidat untuk menjawab permasalahan sangat terbatas dan aturan-aturan dari KPU membuat debat ini tidak hidup dan esensinya bukan debat 
pemilihan presiden. Format ini menyulitkan bagi kandidat untuk menguraikan program kampanye yang mereka usung sehingga jawaban para kandidat menjadi sangat normatif pada permukaan masalah saja. Materi yang disiapkan oleh tim sukses haruslah mendukung kandidat baik pada saat debat dan argumen tim sukses terkait dengan esensi debat capres-cawapres yang disampaikan oleh kandidatnya. Goffman dalam Mulyana (2010 : 121) selain membawa peran dan karakter individu, aktor-aktor sosial juga berusaha mengelola kesan orang lain terhadap kelompoknya, baik itu keluarga, tempat bekerja, partai politik, atau organisasi lainnya yang mereka wakili. Disebut sebagai tim pertunjukan (performance team) yang mendramatisasi suatu aktivitas. Dengan munculnya era social media di kalangan masyarakat maka terjadi pergeseran budaya dalam berkomunikasi. Relasi dan interaktivitas dalam komunikasi mulai tergantikan atau digeser dari model komunikasi yang berkonvensional berupa pertemuan atau percakapan face to face menjadi model komunikasi melalui jaringan social media yang ada. Media sosial berbeda dengan media mainstream atau media konvensional. Media sosial seperti FB dan twitter merupakan media kampanye yang membuat pesan menjadi viral. Tim kampanye kandidat Jokowi - JK memiliki banyak pendukung dan menggunakan sosial media sebagai salah satu media kampanye. Facebook menjadi salah satu yang fenomenal dalam Pilpres 2014 ini. FB sebagai sarana kampanye kandidat terbagi atas berbagai tema baik dari pihak Jokowi - JK maupun lawan politiknya. Kampanye politik viral dengan menggunakan media online ini merupakan bagian dari kampanye kandidat presiden Jokowi - Jk pada Pilpres 2014. Berbagai pesan di share atau disampaikan melalui $\mathrm{Fb}$ dan kemudian menjadi viral diantara pendukung calon. Tim kampanye Jokowi-JK mendasari kegiatanya kampanye politik viral dengan menggunakan tahapan POST. People: Voter Jokowi adalah mereka dengan tingkat pendidikan SMA-S3, muslin dan non muslim, pribumi dan keturunan. Objectif: untuk memenangkan pemilihan. Strategi: Jokowi, menggunakan strategi viral merakyat, blusukan, dan kerja nyata. Teknologi menggunakan media sosial untuk kampanye. Strategi kandidat dalam menyosialisasikan program menggunakan meda sosial dan menjadikan follower sebagai agent kampanye. Pesan menjadi viral karena keterlibatan voter dalam kampanye. Jenis follower yang merupakan partisipan kandidat juga beragam terbagi akan berbagai tingkatan. Follower yang masuk dalam kategori Creators sangat sedikit, creators merupakan mereka yang membuat konten yang memberikan informasi yang kemudian menjadi viral. Informasi bukan hanya berupa data dari lembaga resmi tapi juga opini, meme, tulisan, video, maupun hasil riset.

\section{SIMPULAN}

Strategi kampanye Jokowi-Jk pada Pilpres 2014 dibentuk dengan menjalankan langkah-langkah: analisis khalayak, penetapan tujuan, perencanaan, pesan, rancangan strategi dan implementasi kampanye. Implementasi kampanye politik Jokowi - Jk adalah blusukan, pesta rakyat, slogan pesan "salam dua jari", ikon penggunaan pakaian putih dan kotak-kotak, debat politik dan menggunaan media sosial dalam kampanye pemilu 2014. Kegiatan pesta rakyat merupakan ajang pertemuan antara Jokowi dengana pendukungnya yang berbentuk acara konser dan kebersamaan dimana pengisi acara merupakan partisipasi pendukung yang terdiri dari arti, penyanyi, group band, dan lainnya. Blusukan merupakan kegiatan yang telah lama Jokowi lakukan dan tetap dilakukan pada masa kampanye dengan mengunjungi berbagai temoat dan masyarakat.

Slogan salam dua jari menjadi penanda bagi pendukung Jokowi - Jk pda Pilpres 2014. Selain itu kemeja putih yang digulung merupakan lambang kesederhanaan dan pekerja. Kotak-kotak menajdi bagian dari identitas Jokowi dengan kemejanya yang menjadi identitas bagi para pendukungnya. Gaya komunikasi Jokowi yang sangat sederhana dan jauh dari birokrasi mengkonstruksikan citra merakyat Jokowi. Strategi kampanye politik bekerja bersama rakyat, partisipasi aktif dalam segala kegiatan kampanye politik Jokowi JK. Kampanye dilakukan baik face-to-face maupun melalui media massa dan media online. Mesia massa televisi menjadi salah satu media 
menyampai visi misi melalui program debat politik pilpres 2014. Media online menjadi alat kampanye oleh Jokowi-JK dengan memanfaatkan Facebook, twiiter, instagram, dan website.

\section{DAFTAR PUSTAKA}

Arifin, Anwar. 2003. Komunikasi Politik:Paradigma-Teori-Aplikasi, Strategi dan Komunikasi Politik di Indonesia, Jakarta : Balai Pustaka.

Cangara,Hafied.2009. KomunikasiPolitik:Konsep, Teori, danStrategi. Jakarta:Rajawali Pers.

Firmanzah. 2008. Marketing Politik; Antara Pemahaman dan Realitas Jakarta: Yayasan Obor Indonesia.

Kaid, Lynda Lee. 2004. Handbook of Political Communication Research. New Jersey : Lawrence Erlbaum associates, Inc.

Kaid, Lynda Lee and Christina Holtz-Bacha. 2006. The Handbook ofPolitical Advertising. California : Sage Publications, Inc.

Kavanagh, Denis. 1995. Election Campaign: The New Marketing of Politics. Blackwell.

Kriyantono, Rachmat. 2009. Teknik Praktek Penelitian Komunikasi, Jakarta: Kencana Penada Media Grup.

Lilleker, Daren, G. 2006. Political Communication. London : Sage Publications.

Macini, Paolo and David L. Swanson, 1996. Politics, Media, and Modern Democracy: Introduction. In Politics, Media, andModern Democracy: An International Study of Innovations in Electoral Campaigning and their Consequences, edts. Westport,USA:
Greenwood Publishing Group.

Mc. Nair, Brian. 2003. An Introduction to Political Communication. London, Routledge.

Mc. Nair, Brian. 2010. An Introduction to Political Communication. New York: Routledge.

Miles, Matthew. B \& A. Michael Huberman, 1992. Analisis Data Kualitatif (Terjemahan Tjetjep Ruhendi Rahidi), Jakarta : UIPress.

Moleong. 2006. Metode Penelitian Kualitatif, Bandung : PT. RemajaRosdakarya.

Mulyana, Deddy. 2001. Metode Penelitian Kualitatif, Bandung : PT Remaja Rosdakarya.

Mulyana, Deddy. 2010. Metode Penelitian Kualitatif. Bandung : PT. Remaja Rosdakarya.

Nasution, Zulkarimen. 1990. KomunikasiPolitik:S uatuPengantar. Jakarta: Ghalia Indonesia

Nimmo, Dan. 1990. Komunikasi Politik, Komunikator, Pesan, dan Media. Bandung: Remaja Rosdakarya.

Ruslan, Rosady. 2007. Manajemen Public Relations dan Media Komunikasi : Konsepsi dan Aplikasi. Jakarta : Rajawali Pers.

Salim,Agus. 2006. Teori Dan ParadigmaPenelitian Sosial, Yogyakarta: TiaraWacana.

Sugiyono. 2005. Memahami Penelitian Kualitatif, Bandung: Alfabeta.

Suwardi, Harsono, Sendjaja, Sasa Djuarsa dan Budi Setio. 2002. Politik Demokrasi dan Manajemen Komunikasi. Yogyakarta: Galanmg Press. 